\title{
Isolation and Identification of H9N2 Avian Influenza and Newcastle Disease Viruses co-Infections in Chicken.
}

\author{
M. M. Amer", Asmaa M. Maatouq ${ }^{* * *}$, G.A. Abdel-Alim*, M. H. H. Awaad* and M. \\ A. Kutkat** \\ *Department of Poultry Diseases, Faculty Veterinary Medicine, Cairo University, \\ P.O. 12211 and **Department of Poultry Diseases, Veterinary Research Division, \\ National Research Centre, P.O. 12622, Cairo, Egypt.
}

\begin{abstract}
CO-infections with Newcastle disease (ND) and avian influenza (AI) highly pathogenic viruses causes high mortality and high economic losses. In this study, 322 samples were collected from 50 chicken flocks suffering from respiratory symptoms, severe drop in egg production and mortalities from December, 2013 to December, 2014. Real time polymerase chain reaction (RT-PCR) was performed to detect the M protein of $\mathrm{H} 9$ gene of AI and F gene of velogenic ND virus (vNDV) co-infection. H9 PCR was 20 and 34 in cloacal and pharyngeal swabs with total percentage of $6.2 \%$ and $10.5 \%$, respectively. The H9 sequences showed low pathogenic RSSR/GLF motif. The phylogenetic tree showed that $\mathrm{H} 9$ sequences belong to the G1 lineage which clustered with 2015 -2016 Egyptian H9N2. Partial sequences of the Fusion gene revealed that the isolated NDV isolates belong to class II genotype VIIj. The cleavage site of the F protein showed the presence of a polybasic amino acid motif (112RRQKRF117) suggesting that our two isolates were vNDV strain. The molecularly identified H9 (1 isolate) and NDV Genotype VII (2 isolates) were named AI/CHICKEN/EGYPT/48Ob/NRC-CU/2014(H9), NDV/CHICKEN/EGYPT/48Ob/NRC-CU/2014, and NDV/CHICKEN/EGYPT/66Oc/NRC$\mathrm{CU} / 2014$, and nucleotide sequences were submitted to GenBank and given accession numbers MG966504, MG966505, and MG966506, respectively. Conclusion: Natural mixed infections with AIV H9N2 and virulent NDV genotype VIIj viruses were detected in chicken flocks suffering from respiratory symptoms and mortalities in Egypt.
\end{abstract}

Keywords: H9N2, NDV genotype VII, Co-infection, RT-PCR, Phylogenies.

\section{Introduction}

Low pathogenic avian influenza virus (LPAIV) H9N2 and Newcastle disease virus (NDV) are the main respiratory causes of high mortality rates in broiler chicken flocks [1]. Infections of domestic poultry with AI H9N2 viruses are usually in mild form result in decreased feed and water consumption and decreased egg production with mild respiratory signs and low mortality [2]. However, during the last years, outbreaks of LPAIV H9N2 infections in commercial poultry flocks appeared to be associated with severe clinical signs, variable high mortality $(20 \%$ $65 \%$ ) and high reduction in egg production (up to $75 \%$ ) as reported by Suarez [3]. Similar findings in Hong Kong, an outbreak of H9N2 influenza virus (A/chicken/Hong Kong/739/94) infection were reported in which $75 \%$ of infected chickens showed coughing and respiratory distress associated with $10 \%$ mortality. It was reported that North American and the Eurasian lineages are the major two genetic lineages of H9N2 viruses circulating in poultry $[4,5]$. Phylogenetically, the Eurasian avian H9N2 viruses are genetically differentiated into 3 main sublineages: the G1 lineage, the Y280 and the Korean lineage represented by their prototype strains A/Qa/HK/G1/97, A/Dk/HK/Y280/97 and A/Ck/Korea/38349-p96323/96, respectively [6]. Evolution, molecular epidemiology and historical studies of H9N2 isolates have investigated that H9N2 viruses had been evolved gradually into several sublineages from the Eurasian lineage [7].

In Egypt Many investigators reported that poultry flocks were affected with NDV belongs to class II, genotype VII subgenotype VIIb and subgenotype VIId [8-12].

Mixed infection by AI subtype H9N2 and NDV causes a major veterinary health crisis, resulting in great loss among poultry flocks. Natural field 
mixed infections of NDV and LPAIV have been reported many times in poultry $[13,14]$. LPAI H9N2 subtype has been favors the occurrence of NDVAI mixed infections in backyard and commercial farms of layers, breeders, broilers and turkeys in the Middle East [15]. The presence of good immunity against NDV, vaccine breaks of vNDV have caused drops in egg production and mortality events often reported in association with H9N2 infections [16]. This suggests a role of this pathogen in the sustained circulation of NDV in the region. Gowthaman et al. [17] reported that $18 / 48$ of tested flocks $(37 \%)$ were positive for the isolation of hemagglutinating agents, 11 flocks (61\%) out of 18 HA positive flocks were positive for AIV and NDV. Taher $e t$ al. [18] showed that 41 out of 180 broiler farms were positive for either Infectious bronchitis virus (IBV) or vNDV or AI-H5 and AI-H9 as a single infection as follows: $24,10,5$ and 2 farms, respectively.

Real time -polymerase chain reaction (RTPCR) as a molecular diagnostic assay showed superior in sensitivity and acceptability as a gold standard [19-21].

This study was conducted for isolation, molecular characterization and detection of genetic diversity of AI H9N2 and ND viruses in natural field mixed infection among chicken flocks.

\section{Material and Methods}

Samples collection and processing

A total of 322 cloacal and or pharyngeal swabs were collected from December, 2013 to December, 2014) from 50 chickens flocks in five separate Governorates (Cairo, Qalubiya, Sharkia, Dakahlia and Menuofiya). These flocks were suffering from respiratory symptoms, sever drop in egg production and high mortalities. Swabs were collected in transport medium $(1 \mathrm{ml} /$ swab) which consisted of $50 \%$ glycerol, $50 \%$ Phosphate buffer saline (PBS) with penicillin $\left(2 \times 10^{6} \mathrm{U} /\right.$ liter $)$, streptomycin $(200 \mathrm{mg} /$ liter $)$, and amphotericin B $(250 \mathrm{mg} / \mathrm{liter}$, Lonza, Walkersville, MD). Samples were stored at $80^{\circ} \mathrm{C}$ until tested.

Specific Pathogen Free (SPF) chicken eggs

Fertile SPF chicken eggs were used for virus propagation. Embryonated eggs were inoculated at the $9^{\text {th }}$ day of age via allantoic sac rout according to OIE [22].

\section{Extraction of viral RNA}

The genomic viral RNA was extracted from sample swabs and haemagglutination (HA) positive allantoic fluid of inoculated SPF embryonated eggs by using QIAamp viral RNA extraction Kits according to the manufacture's protocol.

\section{Virus isolation and propagation}

Samples that showed partial M segment RTPCR positive reaction were inoculated separately in allantoic sac of 10-day-old SPF chicken eggs, further incubated at $37.5^{\circ} \mathrm{C}$ for $48 \mathrm{~h}$, chilled at $4^{\circ} \mathrm{C}$ for $4 \mathrm{~h}$ and allantoic fluid was tested for the presence of haemagglutinating activity using HA test. HA positive allantoic fluid was harvested, labeled and kept frozen for further investigations.

\section{Haemagglutination (HA) test}

HA test was performed with $0.5 \%$ chicken red blood cells (CRBCs) by a standard method according to WHO [23].

\section{Detection of AIV and NDV}

All extracted viral RNA from collected samples were screened for detection of influenza A virus matrix (M) gene by Real-Time-PCR (RRT-PCR) using the primers (Table 1) designed by CDC [24]. Samples that were positive for the $\mathrm{M}$ segment were then subjected to H5, and H9 hemagglutinin subtyping by conventional RT-PCR according WHO [23]. RT-PCR was conducted for detection of NDV F-gene using specific primers (Table 1) in samples that showed a positive reaction for typing and subtyping AIV. Field samples previously confirmed to be positive (for the related genes) in our laboratory were used as positive control, while negative control was PCR mixture + sterilized water.

\section{Amplification of the full HA influenza gene}

Amplification of the full HA influenza gene in the extracted viral RNA from harvested allantoic fluid were done using universal primers [28] according to the manufacturer's instructions. Thermal cycling RT-PCR conditions included a reverse transcription $50^{\circ} \mathrm{C}$ for $30 \mathrm{~min}$. then an Initial PCR activation step $95^{\circ} \mathrm{C}$ for $15 \mathrm{~min}$. followed by 40 cycles at $94^{\circ} \mathrm{C}$ for $30 \mathrm{sec}$., $58^{\circ} \mathrm{C}$ for $30 \mathrm{sec}$. and $72^{\circ} \mathrm{C}$ for $1 \mathrm{~min}$., then the final extension was performed at $72^{\circ} \mathrm{C}$ for $10 \mathrm{~min}$. The PCR products of all samples showed a positive band in electrophoresis were purified using QIAquick PCR purification kit, using the PCR purification protocol. 
TABLE 1. The used primers for avian influenza and vNDV .

\begin{tabular}{|c|c|c|c|c|c|}
\hline Type & $\begin{array}{c}\text { Target } \\
\text { fragment }\end{array}$ & Primer & Primer sequence & $\begin{array}{c}\text { Expected } \\
\text { product } \\
\text { size } \\
\end{array}$ & Reference \\
\hline \multirow{3}{*}{$\mathrm{AI}$} & \multirow{3}{*}{$\begin{array}{l}\text { Matrix } \\
\text { (M) }\end{array}$} & Inf-A F & ACCRATCCTGTCACCTCTGAC & \multirow{3}{*}{$\begin{array}{l}\text { Real time } \\
\text { PCR }\end{array}$} & \multirow{3}{*}{$\begin{array}{l}\text { CDC } \\
{[24]}\end{array}$} \\
\hline & & Inf-A R & AGGGCATTYTGGACAAAKCGTCTA & & \\
\hline & & $\begin{array}{l}\text { Inf-A } \\
\text { POB }\end{array}$ & FAM TGCAGTCCTCGCTCACTGGGCACG BHQ1 & & \\
\hline \multirow{2}{*}{ H5 } & \multirow{2}{*}{ HA } & H5-kha-1 & 5'-CCTCCAGARTATGCMTAYAAAATTGTC-3' & \multirow{2}{*}{$311 \mathrm{bp}$} & \multirow{2}{*}{$\begin{array}{c}\text { Slomka et } \\
\text { al. [25] }\end{array}$} \\
\hline & & H5-kha-3 & 5'-TACCAACCGTCTACCATKCCYTG-3' & & \\
\hline \multirow{2}{*}{ H9 } & \multirow{2}{*}{ HA } & H9-151f & 5'-CTYCACACAGARCACAATGG- 3' & \multirow{2}{*}{$488 \mathrm{bp}$} & \multirow{2}{*}{$\begin{array}{c}\text { Lee et al., } \\
\text { [19] }\end{array}$} \\
\hline & & H9-638r & 5'-GTCACACTTGTTGTTGTRTC-3' & & \\
\hline \multirow[t]{2}{*}{ NDV } & \multirow{2}{*}{ F gen } & NDV F & 5' -GGTGAGTCTATCCGGARGATACAAG-3 & \multirow{2}{*}{$202 \mathrm{bp}$} & \multirow{2}{*}{$\begin{array}{l}\text { Creelan } \\
\text { et al. [26] }\end{array}$} \\
\hline & & NDV R & 5' -TCATTGGTTGCRGCAATGCTCT-3 & & \\
\hline \multirow{2}{*}{$\mathrm{AI}$} & \multirow{2}{*}{ HA } & BM-HA-1 & TATTCGTCTCAGGGAGCAAAAGCAGGGG & \multirow{2}{*}{1778} & \multirow{2}{*}{$\begin{array}{l}\text { Hoffmann } \\
\text { et al. [27] }\end{array}$} \\
\hline & & $\begin{array}{c}\text { BM-NS- } \\
890 \mathrm{R}\end{array}$ & ATATCGTCTCGTATTAGTAGAAACAAGGGTGTTTT & & \\
\hline \multirow{2}{*}{ NDV } & \multirow{2}{*}{$\mathrm{F}$} & F47 & ATGG GC(C/T)CCAGA(C/T)CTTCTAC & \multirow{2}{*}{535} & \multirow{2}{*}{ Seal $[28]$} \\
\hline & & $\mathrm{F} 2$ & CTGCCACTGCTAGTTGTG ATAATCC & & \\
\hline
\end{tabular}

Amplification of partial F NDV genome

Partial F NDV genome by thermal cycling RTPCR conditions included a reverse transcription $50^{\circ} \mathrm{C}$ for $30 \mathrm{~min}$. then an Initial PCR activation step $95^{\circ} \mathrm{C}$ for $15 \mathrm{~min}$. followed by 40 cycles at $94^{\circ} \mathrm{C}$ for $30 \mathrm{sec}$., $55^{\circ} \mathrm{C}$ for $30 \mathrm{sec}$. and $72^{\circ} \mathrm{C}$ for $45 \mathrm{sec}$. then the final extension was performed at $72^{\circ} \mathrm{C}$ for $10 \mathrm{~min}$. The PCR products of all samples showed a positive band in electrophoresis were purified using the QIAquick PCR purification kit, using the PCR purification protocol.

\section{Amplification of partial F NDV genome}

Partial F NDV genome by thermal cycling RTPCR conditions included a reverse transcription $50^{\circ} \mathrm{C}$ for $30 \mathrm{~min}$. then an Initial PCR activation step $95^{\circ} \mathrm{C}$ for $15 \mathrm{~min}$. followed by 40 cycles at $94^{\circ} \mathrm{C}$ for $30 \mathrm{sec} ., 55^{\circ} \mathrm{C}$ for $30 \mathrm{sec}$. and $72^{\circ} \mathrm{C}$ for $45 \mathrm{sec}$. then the final extension was performed at $72^{\circ} \mathrm{C}$ for $10 \mathrm{~min}$. The PCR products of all samples showed a positive band in electrophoresis were purified using the QIAquick PCR purification kit, using the PCR purification protocol.

\section{DNA sequencing}

Purified PCR products were used directly for sequencing reactions using a BigDyeR Terminator v3.1 Cycle Sequencing Kit (Applied Biosystems, Foster City, CA). Kits were used according to instructions of the manufacturer. Further, amplified for 26 cycles at $95{ }^{\circ} \mathrm{C}$ for $30 \mathrm{sec}, 50{ }^{\circ} \mathrm{C}$ for 15 sec, and $60{ }^{\circ} \mathrm{C}$ for $4 \mathrm{~min}$ were done. The reaction product was purified by exclusion chromatography in CentriSep columns (Princeton Separations, Adelphia, NJ). The recovered materials were sequenced using a 96-capillary 3730xl DNA Analyzer (Applied Biosystems). Sequences were assembled using SeqMan DNA Lasergene 7 software (DNASTAR, Madison, WI, USA).

Sequence analysis and Phylogenetic analysis:

Multiple sequence alignment was done using MegAlign (DNASTAR) and BioEdit 7.0 according to Hall [29]. Percent identity matrices comparing the genes under study to each other were obtained. MEGA 7.0 was used for phylogenetic tree construction of the full HA influenza gene and partial F NDV gene by applying the neighborjoining method with Poisson correction and 1000 bootstrap replicates. The obtained nucleotide sequences were compared with those of H9N2 and NDV available in GenBank (Fig. 1-3)

Egypt. J. Vet. Sci. Vol. 49, No.2 (2018) 


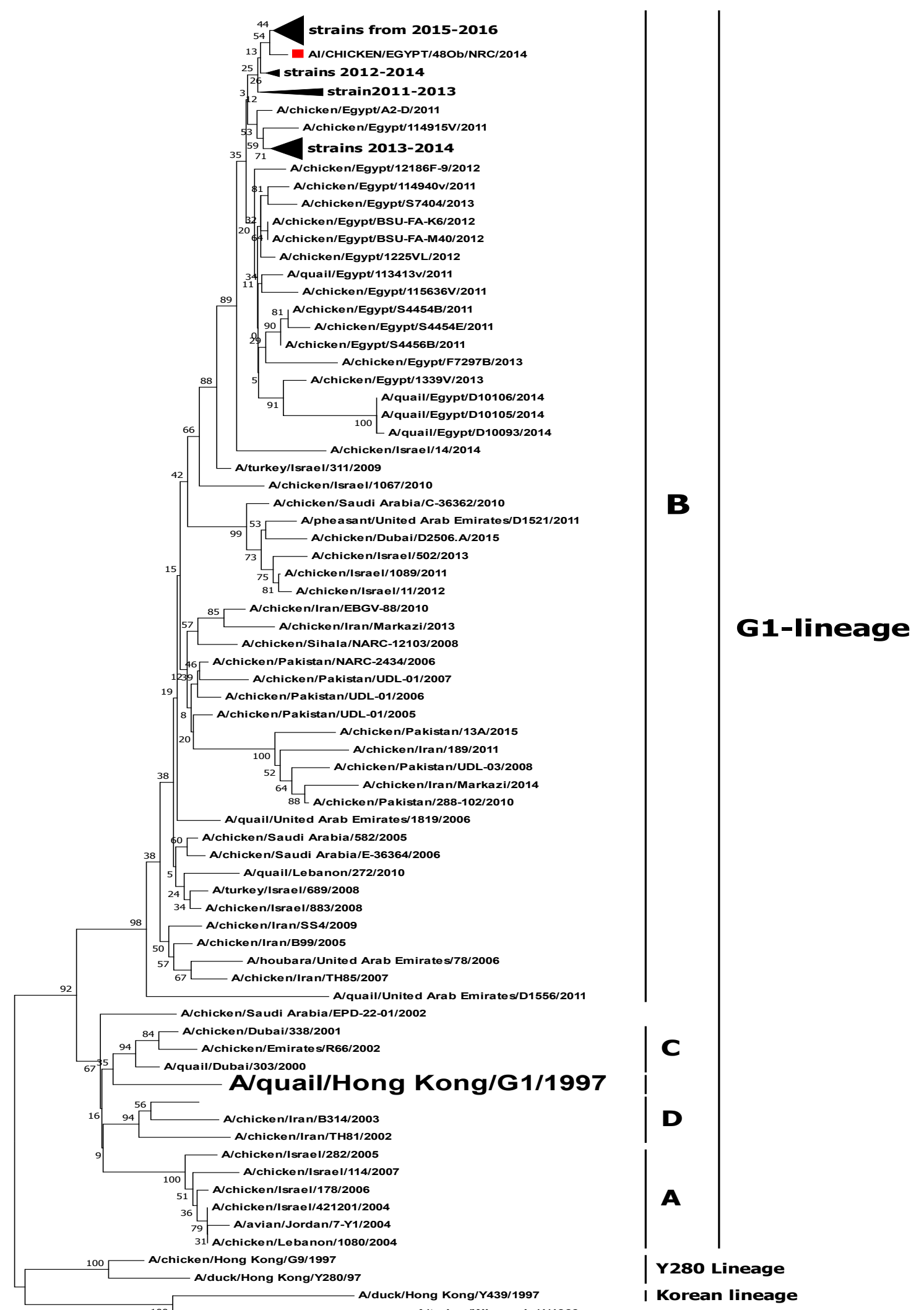

Fig. 1. Phylogenetic tree of amino acid sequences of haemagglutinins of isolated AI H9 .The virus used in this study indicated by (Solid Square).

Egypt. J. Vet. Sci. Vol. 49, No.2 (2018) 


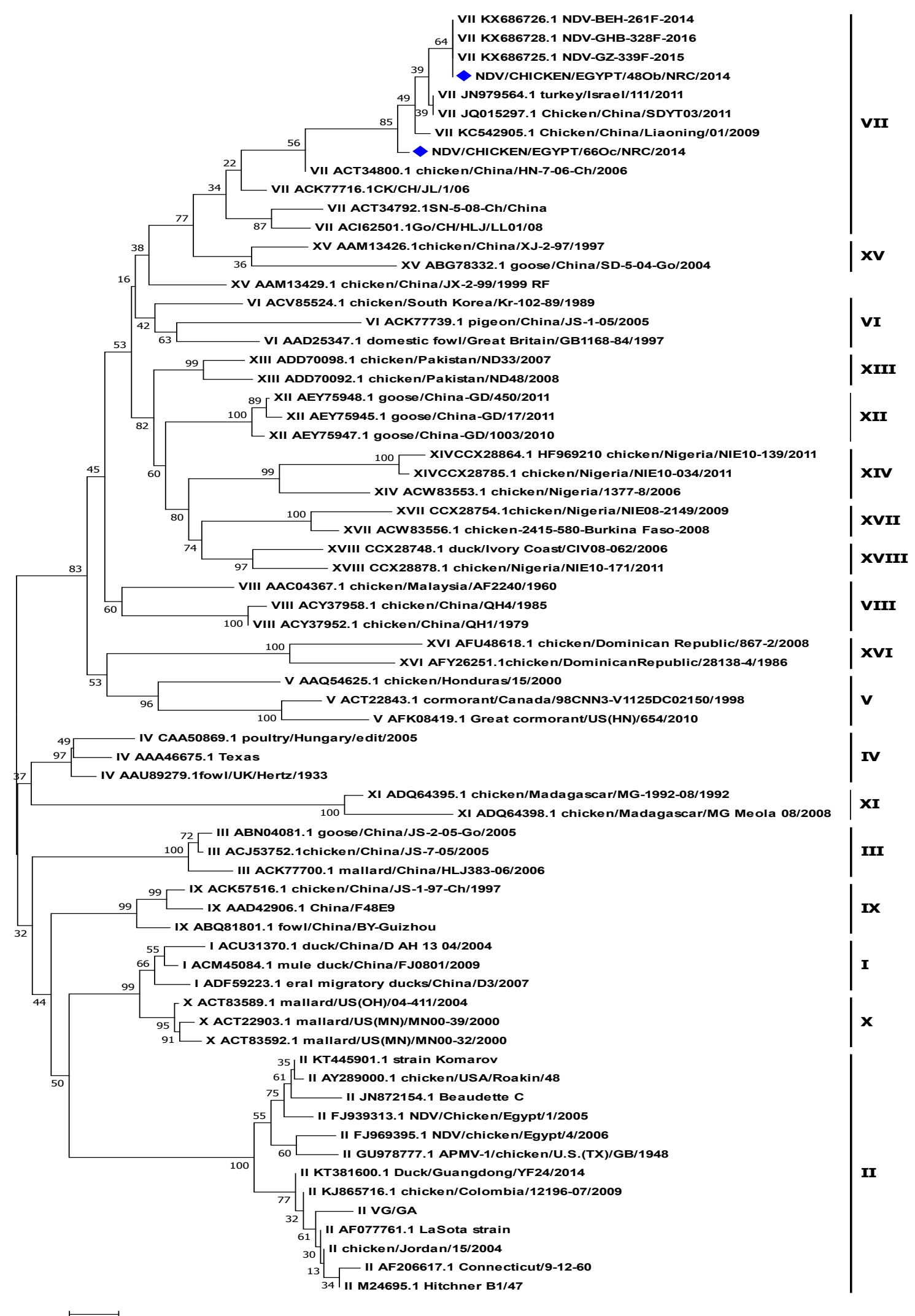

Fig. 2. Phylogenetic tree of $\mathbf{F}$ gene partial sequence of NDV isolates as compared with other NDV class II representative strains from GenBank. Sequences used in this study are indicated by a solid square. 


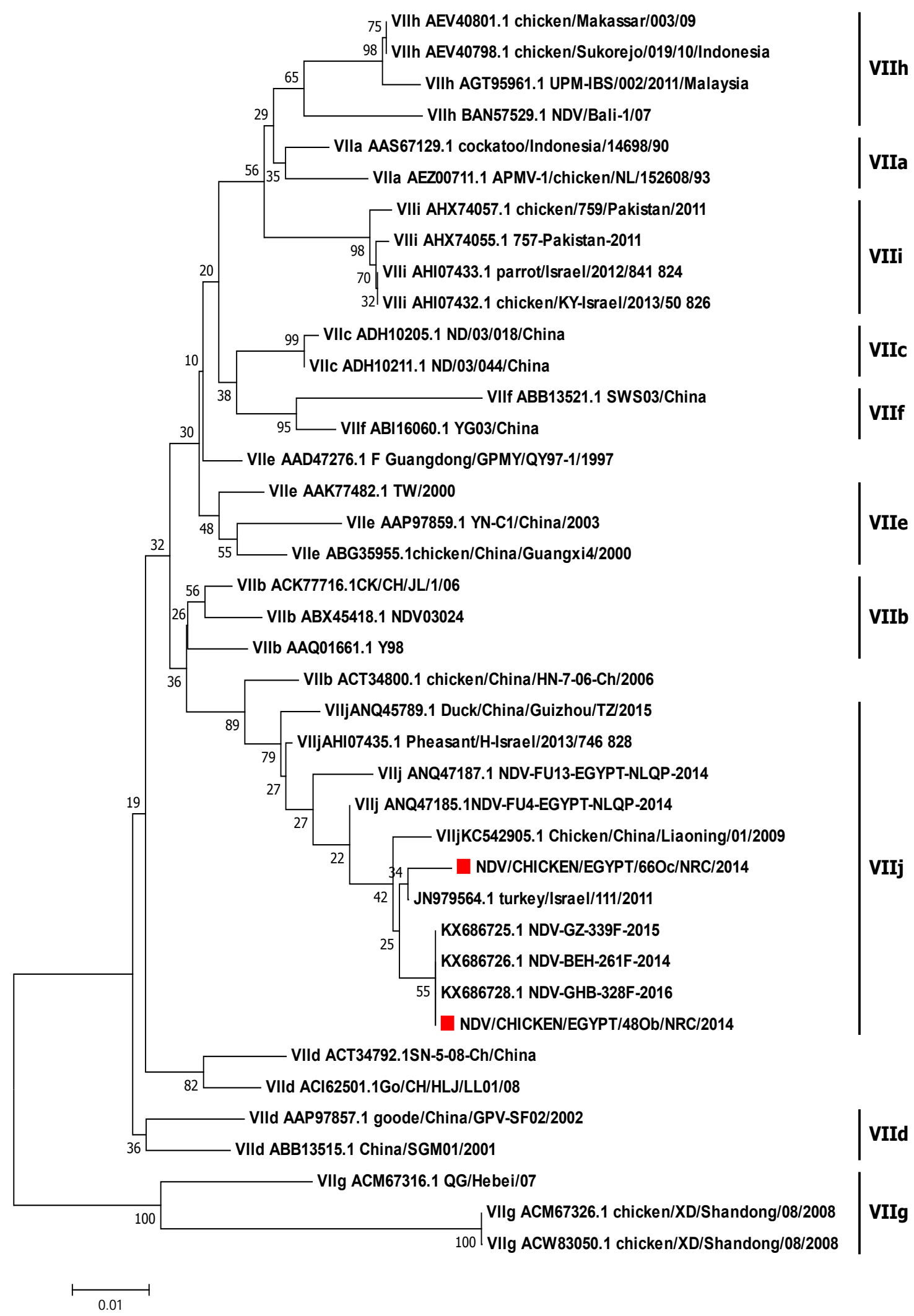

Fig. 3. NDV genotype VII phylogenetic tree using partial nucleotide sequences as compared with the NDV-F gene Sequences from GenBank. Our stained in this study are indicated by a solid square. 
TABLE 2. Positive results of RT-PCR test for avian influenza matrix (M) gene in pharyngeal and cloacal swabs.

\begin{tabular}{|c|c|c|c|c|c|c|c|}
\hline \multirow{2}{*}{ Samples type } & \multirow{2}{*}{ No. } & \multicolumn{3}{|c|}{ Influenza A } & \multirow{2}{*}{$\begin{array}{c}\text { H5 } \\
\text { No. }(\%)\end{array}$} & \multirow{2}{*}{$\begin{array}{c}\text { H9 } \\
\text { No. }(\%)\end{array}$} & \multirow{2}{*}{$\begin{array}{l}\text { H5+ H9 } \\
\text { No. }(\%)\end{array}$} \\
\hline & & $\mathrm{Ct}<36$ & $\mathrm{Ct}>36$ & No. (\%) & & & \\
\hline $\begin{array}{c}\text { Oropharyngeal } \\
\text { swabs }\end{array}$ & 165 & 36 & 9 & $45(13.9 \%)$ & $13(4 \%)$ & $34(10.5 \%)$ & (11) $3.4 \%$ \\
\hline $\begin{array}{l}\text { Cloacal } \\
\text { swabs }\end{array}$ & 157 & 21 & 9 & $30(9.3 \%)$ & $14(4.3 \%)$ & $20(6.2 \%)$ & (10) $3.1 \%$ \\
\hline Total & 322 & 57 & 18 & $75(23.2 \%)$ & $27(8.3 \%)$ & $54(16.7 \%)$ & (21) $6.5 \%$ \\
\hline
\end{tabular}

\section{Results}

Seventy fife samples tested for influenza A were positive by matrix gene RT-PCR positive (57samples showed $\mathrm{Ct}$ value $<36$ and 18 were $\mathrm{Ct}$ >36). Positive results from or pharyngeal swabs was higher $(13.9 \%, 4 \%$ and $10.5 \%$ for Influenza $\mathrm{A}, \mathrm{H} 5$ and $\mathrm{H} 9$, respectively) than cloacal swabs $(9.3 \%, 4.3 \%$ and $6.2 \%$ for Influenza A, H5 and H9, respectively) (Table 2). The total 75 positive samples out of $322(23.2 \%)$ were represented H5, $\mathrm{H} 9$ and $\mathrm{H} 5+\mathrm{H} 9$ subtypes in rates of $27(8.3 \%)$ $54(16.7 \%$ ) and (21) $6.5 \%$, respectively (Table 2).

Positive swabs for AI matrix (M) gene segment RRT-PCR with $\mathrm{Ct}$ values $<36$ were inoculated in 10 days SPF chicken embryos and harvested allantoic fluid showed that 35 samples were positive with HA titre ranged from $\log _{2} 5$ to 12 .

HA positive allantoic fluids of passed swabs were subjected to RT-PCR assay for detection of $\mathrm{M}$ segment of $\mathrm{H} 9$ and F gene of subtype vNDV. Positive results was proved in 25, 13 and 2 for $\mathrm{H} 9$, vNDV and mixed vNDV with $\mathrm{H} 9$, respectively.

Two vNDV isolates and one H9N2 isolate were named, sequenced and the obtained sequences were submitted to GenBank and given accession numbers MG966504, MG966505, and MG966506, respectively.

The phylogenetic analysis of full HA sequence of a single selected AI H9 isolate was named AI/ CHICKEN/EGYPT/48Ob/NRC-CU/2014(H9). The amino acid sequences of the HA protein of our isolate shared 95.5- 99.1\% homology with Egyptian strains. The deduced mino acid sequences at the cleavage site of HA contained low pathogenic RSSR/GLF motif. Phylogenetic analysis of the HA protein indicated our strain no:
MG966504 was belonged to the A/quail/Hong Kong/G1/97-like virus lineage clustered with group B (Fig.1). The isolated strains were closely related to Egyptian strains which were prevalent in 2015-2016 with identities of 98.7-99.1\%.

The amino acid sequences of the $\mathrm{F}$ protein of the circulating isolates NDV/CHICKEN/ EGYPT/48Ob/NRC-CU/2014 (MG966505) and NDV/ CHICKEN/ EGYPT/ 66Oc/ NRCCU/2014 (MG966506) shared 93-100\% homology with Egyptian strains and 82.7-87.3\% with vaccine strains. Sequencing of the region corresponding to the $\mathrm{F}$ protein cleavage site was ${ }^{112} \mathrm{RRQKRF}^{117}$, suggesting that our two isolates were vNDV strain.

Phylogenetic analysis of our isolates MG966505 and MG966506 are belong to class II, related to genotype VII with reference to the nomenclature described by Diel et al. [30] (Fig.2) in a new sub-genotype named VII-(j) (Fig.3) identified by the phylogenetic differences and evolutionary distances using the criteria previously established by Xue, et al. [31].

\section{Discussion}

Poultry respiratory diseases have been reported to be caused by single or mixed infections with several microbial agents and non-microbial factors [32, 33]. Many authors documented natural mixed infections with NDV and LPAIV in domestic poultry $[13,14]$. NDV and LPAIV are the main respiratory causes in broiler chicken flocks $[14,34]$. ND and LPAI viruses in association with each other can cause disease, or with pathogenic bacterial agents [35, 36]. H9N2 infection showed no overt symptoms or mild respiratory signs unless the infection is complicated with other pathogens $[35,36]$.

Egypt. J. Vet. Sci. Vol. 49, No.2 (2018) 
This study revealed high detection rates of H9 in chicken flocks with no history of H9 vaccination. Similar findings were reported by others [39-41].

High detection rate percentage of $\mathrm{H} 9$ in pharyngeal swabs $[34(10.5 \%)]$ was higher as compared with cloacal swabs [20(6.2\%)]. This result suggested that LPAI H9 is a primarily respiratory disease in poultry and replicates mainly in the respiratory tract in gallinaceous birds as reported by Swayne and Halvorson [2]. The mixed infection of chickens with AIV-H9 and NDV even in vaccinated flocks can lead to increase mortalities as previously reported by Banet-Noach et al. [16].

Phylogenetic analysis of HA of H9 strain showed that these isolates are closely related to H9N2 viruses of Middle Eastern countries group B. The Egyptian viruses shared the common ancestor A/quail/Hong Kong/G1/1997 prototype. The isolates in this study were clustered with 2015 -2016 Egyptian H9N2 virus sequences which are available in the GenBank database. The HA cleavage motif sequence of our strain ${ }^{335} \mathrm{RSSR}^{*} \mathrm{GLF}^{341}$ (H9 numbering) suggesting that our isolates was low pathogenic.

Potential glycosylation sites were predicted as NXS/T motifs, in which $\mathrm{X}$ is any amino acid except proline. Changes in the glycosylation patterns of HA can affect host range and virulence of influenza viruses. In Egyptian strains found lack of 2 glycosylation sites compared with A/quail/Hong Kong/G1/1997 prototype [40]. Antigenic conservation of different Egyptian H9N2 isolates from chickens, pigeons and ducks was observed and co-circulation with these infections provides a possibility to generate novel reassortant viruses [40].

The identified NDV VII genotypes are currently divided into subgenotypes VIIa-VIIi [42], although some sporadic novel VIIj were found in last year's [43]. Genotype VII viruses have been associated with recurrent poultry outbreaks in Eastern Europe, Asia and Middle East followed by sporadic events in both Africa and South America, making this genotype of ND viruses of significant global economic importance [44]. Furthermore, In the 1990s and in the beginning of $21^{\text {st }}$ century sub-genotype VIIb have been reported to be associated with outbreaks in poultry in many countries including Turkey, South Africa, Europe, Mozambique,
Kazakhstan, Far East and Middle East as well as India $[11,12,45-47]$.

Analysis of amino acid sequence and phylogenetic analysis of the NDV F-gene proved that the obtained isolates is belong to class II, genotype VII, sub genotype VIIj which close related and clustered with another reference sub genotype VIIj According to evolutionary divergences, VIIj Chinese viruses may have played a crucial role in the emergence of VIIj isolates leaded to appearance of this novel VIIj subgenotype so further studies needed to explain [48].

Sequencing of the $\mathrm{F}$ protein cleavage site corresponding region showed that its amino acid sequence was ${ }^{112} R_{R Q K R F}{ }^{117}$, suggesting that our two isolates were vNDV strain as previously reported [9,10,49-51].

In conclusion: Results of this study pointed out that the presence of LPAI H9 and virulent NDV Genotype VIIj in mixed naturally infected chicken flocks with respiratory symptoms and mortalities. Therefore, further studies for monitoring and epidemiology of NDV and avian influenza in Egypt are recommended to determine evolution and the impact of co-infection with both viruses on poultry industry in Egypt.

\section{Ethical approval}

This study was approved from the Institutional Animal Ethics Committee and in accordance with local laws and regulations.

\section{Authors' Contributions}

MMA and MHHA designed, planned this study, drafted and revised the manuscript. MAK, supervised the practical work and sampling. AMA and GAA shared in samples collection, performing the tests. All authors share manuscript writing, data analysis, read and approved the final manuscript.

Acknowledgments: The authors thank the members of Departments of Poultry Diseases, Faculty of Veterinary Medicine, Cairo University and Veterinary Research Division, National Research Centre, who facilitate the application of the molecular techniques.

\section{Funding statements}

The authors declared that they have funded by National Research Centre project NO 11020103.

\section{Conflict of Interests}

The authors declare that there is no conflict of interests regarding the publication of this article. 


\section{References}

1. Haghighat-Jahromi, M., Asasi, K., Nili, H., Dadras, H. and Shooshtari, A.H. Coinfection of avian influenza virus (H9N2 subtype) with infectious bronchitis live vaccine. Arch.Virol., 153, 651- 655 (2008).

2. Swayne, D.E., Halvorson and D.A. Influenza. In: Diseases of Poultry. Saif Y.M., Glisson J.R., McDougald L.R., Nolan L.K., Swayne D.E. (Ed.), Blackwell Publishing, Ames, pp. 153-184 (2008).

3. Suarez, D.L. Influenza A virus. In: Avian Influenza. Edited by Swayne D.E., Blackwell Publishing, Ames, pp. 3-22 (2008).

4. Guo, Y.J., Krauss, S., Senne, D.A., Mo, I.P., Lo, K.S., Xiong, X.P., Norwood, M., Shortridge,K.F., Webster, R.G. and Guan, Y. Characterization of the pathogenicity of members of the newly established H9N2 influenza virus lineages in Asia. Virol., 267 (2), 279-288 (2000).

5. Webster, R.G., Bean, W.J., Gorman, O.T., Chambers, T.M. and Kawaoka, Y. Evolution and ecology of influenza A viruses. Microbiological Reviews, 56, 152-179 (1992).

6. Guan, Y., Shortridge, K.F., Krauss, S., Chin, P.S., Dyrting, K.C., Ellis, T.M., Webster, R.G. and Peiris, M. H9N2 influenza viruses possessing H5N1-like internal genomes continue to circulate in poultry in southeastern China. J. Virol., 74, 9372-9380 (2000).

7. Fusaro, A., Monne, I., Salviato, A., Valastro, V., Schivo, A., Amarin, N.M., Gonzalez, C., Ismail, M.M., Al-Ankari, A.R., Al-Blowi, M.H., Khan, O.A., Maken Ali A.S., Hedayati, A., Garcia Garcia, J., Ziay, G.M., Shoushtari, A., Al-Qahtani, K.N., Capua, I., Holmes, E.C. and Cattoli, G. Phylogeography and evolutionary history of reassortant H9N2 viruses with potential human health implications. J. Virol. , 85, 84138421 (2011).

8. Radwan, M., Darwish, S., El-Sabagh, I., ElSanousi, A., Shalaby, M. Isolation and molecular characterization of Newcastle disease virus genotypes II and VIId in Egypt between 2011 and 2012. Virus Genes 47:311-316respiratory viruses by single-tube multiplex reverse transcription polymerase chain reaction assay. J. Vet. Diagn. Invest., 16, 244-248 (2013).
9. Hagar M. Ahmed, Amer, M.M., Elbayoumi, Kh. M., Amer, S.A., Kutkat, M. A. Identification and Sequencing of Genotype VII of Newcastle Disease Virus From Chicken Flocks In Six Egyptian Governorates. Egypt. J. Vet. Sci., 48 (1) 31- 41 (2017).

10. Hager Magdy M., Amer, M.M., Elbayoumi, Kh.M. , Kutkat, M. A. Isolation and identification of Genotype VII of Newcastle disease virus from chicken flocks in different Egyptian. Specialty J. of Medical Res. and Health Sci., 2 (2) 1-7(2017).

11. Orabi, A., Hussein, A., Saleh, A.A., El-Magd, M.A., Munir,M.Evolutionaryinsightsintothefusion protein of Newcastle disease virus isolated from vaccinated chickens in 2016 in Egypt. Arch. Virol., 162, 3069-3079 (2017).

12.Saad, A.M., Samy, A., Soliman, M.A., Arafa, A., Zanaty, A., Hassan, M.K., Sultan, A.H., Bazid, A,I., Hussein, A.H. Genotypic and pathogenic characterization of genotype VII Newcastle disease viruses isolated from commercial farms in Egypt and evaluation of heterologous antibody responses. Arch Virol. , 162 (7),1985-1994 (2017).

13. Roussan, D. A., Haddad, R. , Khawaldeh G.. Molecular survey of avian respiratory pathogens in commercial broiler chicken with respiratory diseases in Jordan. Poult. Sci. 87, 444- 448 (2008).

14. Couacy-Hymann, E., Kouakou, A.V., Kouame, C.K., Kouassi, A.L.Koffi, Y.M., Godji, P., Nana, P., Tarnagda, Z. , Akoua-Koffi, C. Surveillance for avian influenza and Newcastle disease in backyard poultry flocks in Cote d'Ivoire, 2007-2009. Rev. Sci. Tech., 31, 821- 828(2012).

15. Davidson, I., Fusaro, A., Heidari, A., Monne, I., Cattoli, G. Molecular evolution of H9N2 avian influenza viruses in Israel. Virus Genes, 48, 457463 (2014).

16. Banet-Noach, C., Perk, S., Simanov, L., Grebenyuk, N.,Rozenblut, E., Pokamunski, S., Pirak, M., Tendler, Y., Panshin, A. H9N2 influenza viruses from Israeli poultry: a five-year outbreak. Avian Dis., 51, 290-296 (2007).

17. Gowthaman, V. , Singh, D. S., Dhama, K., Srinivasan, P., Saravanan, S., Murthy, R. G. K. T. , Ramakrishnan, A. M. Molecular Survey of Respiratory and Immunosuppressive Pathogens Associated with Low Pathogenic Avian Influenza H9N2 Subtype and Virulent Newcastle Disease Viruses in Commercial Chicken Flocks. J. Poult. Sci., 54, 179-184 (2017).

Egypt. J. Vet. Sci. Vol. 49, No.2 (2018) 
18. Taher, M.T., Amer, M. M., Arafa, A., Saad, F.E. Epidemiology of viral components causing respiratory problems in broilers in six Egyptian Governorates. J. Vet. Med. Res., 24 (1), 308-320 (2017).

19. Lee, M.S., Chang, P.C., Shien, J.H., Cheng, M.C. , Shieh, H.K.. Identification and subtyping of avian influenza viruses by reverse transcription-PCR. $J$. Virol. Methods, 97, 13-22 (2001).

20. Hodinka, R.L. Point: is the era of viral culture over in the clinical microbiology laboratory? J. Clin. Microbiol., 51, 2- 4 (2013).

21. Létant, S.E., Ortiz, J.I., Tammero, L., Birch, J.M., Derlet, R.W., Cohen, S., Manning, D., McBride, M.T. Multiplexed reverse transcriptase PCR assay for identification of viral respiratory pathogens at the point of care. J Clin Microbiol 45, 3498-3505 (2007).

22. OIE. Newcastle disease. Manual of Diagnostic Tests and Vaccines for Terrestrial Animals. Chapter 2.3.14. http://www.oie.int/ internationalstandardsetting/terrestrial-manual/access-online (2012).

23. WHO. Manual on animal influenza diagnosis and surveillance. $2^{\text {nd }}$ Ed. [cited 2011 Dec 12]. http:// whqlibdoc. who.int/hq/2002/WHO_CDS_CSR NCS 2002.

24. Centers for Disease Control and Prevention. CDC real time RTPCR protocol for detection and characterization of influenza. Atlanta (2007).

25. Slomka, M.J., Pavlidis, T., Banks, J., Shell, W., McNally, A., Essen, S. and Brown, I.H. Validated H5 Eurasian real-time reverse transcriptasepolymerase chain reaction and its application in H5N1 outbreaks in 2005-2006. Avian Dis., 51, 373-7 (2007).

26. Creelan. L.J, Graham.D.A, McCullough, Samuel J. Detection and differentiation of pathogenicity of avian paramyxovirus serotype 1 from field cases using one-step reverse transcriptase polymerase chain reaction. Avian Pathology, 31 (5), 493-499. (2002).

27. Hoffmann, E., Stech, J., Guan, Y., Webster, R.G. and Perez, D.R. Universal primer set for the fulllength amplification of all influenza A viruses. Arch. Virol., 146, 2275-2289 (2001).
28. Seal, B.S. Analysis of matrix protein gene nucleotide sequence diversity among Newcastle disease virus isolates demonstrates that recent disease outbreaks are caused by viruses of psittacine origin. Virus Genes, 11, 217-224 (1995).

29. Hall, T.A. BioEdit: a user-friendly biological sequence alignment editor and analysis for Windows 95/98/NT. Nucleic Acids Symp., 41, 95 98 (1999)

30. Diel, D.G., da Silva L.H.A., Liu, H., Wang, Z. Miller, P.J. and Afonso, C.L. Genetic diversity of avian paramyxovirus type 1: Proposal for a unified nomenclature and classification system of Newcastle disease virus genotypes. Infect. Genet. Evol., 12, 1770- 1779 (2012).

31. Xue, K.S., Stevens-Ayers, T., Campbell, A.P., Englund, J. A., Pergam, S.A., Boeckh, M. and Bloom, J.D. Parallel evolution of influenza across multiple spatiotemporal scales. E life. 27(6):pii: e26875(2017). doi: 10.7554/eLife.26875 (2017).

32. Watanabe, H., Nakanishi, K., Sunaga, T., Takehara, K., Mishima, K., Ooe, R. and Hattori, M. Survey on cause of mortality and condemnations of respiratory diseased broiler flocks. J. Jap. Soc. Poult. Dis. 13, 41-46 (1977).

33. Yashpal, S. M., Devi, P. P., Sagar, M. G. Detection of three avian respiratory viruses by single-tube multiplex reverse transcription polymerase chain reaction assay. J. Vet. Diagn. Invest., 16, 244-248 (2004).

34. Afifi , M.A., El-Kady, M.F., Zoelfakar, S.A. and Abdel-Moneim, A.S. Serological surveillance reveals widespread influenza $\mathrm{A} \quad \mathrm{H} 7$ and $\mathrm{H} 9$ subtypes among chicken flocks in Egypt. Trop Anim Health Prod, 45, 687-690 (2013).

35. Malik, Y.S., Patnayak, D.P., Goyal, S.M. Detection of three avian respiratory viruses by single-tube multiplex reverse transcription polymerase chain reaction assay. J. Vet. Diagn. Invest., 16, 244-248 (2004).

36. Ali, A. and Reynolds, D.L. A multiplex reverse transcription - polymerase chain reaction assay for Newcastle disease virus and avian pneumovirus (Colorado strain). Avian Dis., 44 (4), 938-943 (2000). 
37. Naeem, K., Siddique, N., Ayaz, M. and Jalalee, M.A. Avian influenza in Pakistan: outbreaks of low- and high-pathogenicity Avian influenza in Pakistan during 2003-2006. Avian Dis., 51, 189193 (2007).

38. Monne, I., Hussein, H. A., Fusaro, A., Valastro, V., Hamoud, M. M., Khalefa, R. A., Dardir, S. N., Radwan, M. I., Capua, I. and Cattoli, G. H9N2 influenza A virus circulates in H5N1 endemically infected poultry population in Egypt. Influenza Other Respir. Viruses. 7, 240-243 (2012).

39. Soliman, M., Arafa, A., Tammam, S., Aly, M. and Madbouly, H. Molecular characterization of avian influenza virus subtype H9N2 in poultry in Egypt during 2011-2013 with emerging of a new variant in quails. Global Veterinaria 13, 117-126 (2014).

40. Kandeil, A., El-Shesheny, R., Maatouq, A.M., Moatasim, Y., Shehata, M.M., Bagato, O., Rubrum, A., Shanmuganatham, K., Webby, R.J. and Ali, M.A. Genetic and antigenic evolution of H9N2 avian influenza viruses circulating in Egypt between 2011 and 2013. Archives of Virol., 159, 2861-2876 (2014).

41. Hassan, K.E., Shany, S.A.S., Ali, A., Dahshan, A.M., El-Sawah, A.A. and El-Kady, M.F. Prevalence of avian respiratory viruses in broiler flocks in Egypt 2016. Poult. Sci., 95, 1271-1280 (2016).

42. Putri, D.D., Handharyani, E., Soejoedono, D.S., Setiyono, A., Mayasari, N. L. P. I., Okti, N. and Poetri N. Phylogenetic Analysis of Newcastle Disease Virus Isolated from Vaccinated Chicken in West Java, Indonesia. Advances in Health Sci. Res. (AHSR), 5, $1^{\text {st }}$ Internat. Conf. in One Health (ICOH 2017), 199-204 (2017).

43. Munir, M.T., Chowdhury, M.R. and Ahmed, Z. Emergence of new sub-genotypes of Newcastle disease virus in Pakistan. J Avian Res, 2 (1), 1-7 (2016).

44. Miller, P.J., Haddas, R., Simanov, L., Lublin, A., Rehmani, S.F., Wajid, A., Bibi, T., Khan,T. A., Yaqub, T., Setiyaningsih, S. and Afonso, C.L. Identification of new sub-genotypesof virulent Newcastle disease virus with potential panzootic features. Infect. Genet. Evol. 29, 216-229 (2015).
45. Herczeg, J., Wehmann, E., Bragg, R.R., Travassos, P.M., Hadjiev, G., Werner, O. and Lomniczi ,B. Two novel genetic groups (VIIb and VIII) responsible for recent Newcastle disease outbreaks in Southern Africa, one (VIIb) of which reached Southern Europe. Arch. Virol., 144, 2087-2099 (1999).

46. Alexander, D.J. Newcastle disease in the European Union 2000 to 2009. Avian Pathol. 40 (6), 547-558 (2011).

47. Bogoyavlenskiy, A., Berezin, V., Prilipov, A., Usachev, E., Lyapina, O., Korotetskiy, I., Zaitceva, I., Asanova, S., Kydyrmanov, A. and Daulbaeva, K. Newcastle disease outbreaks in Kazakhstan and Kyrgyzstan during 1998, 2000, 2001, 2003, 2004, and 2005 were caused by viruses of the genotypes VIIb and VIId. Virus Gen., 39, 94- 101 (2009).

48. Hussein, H.A., Emara, M.M. and Rohaim, M.A. Molecular characterization of Newcastle Disease Virus Genotype VIID in Avian influenza H5 N1 Infected Broiler Flock in Egypt. Internat. J. Virol., 10 (1), 46 - 54 (2014).

49. Choi, K.S., Lee, E.K., Jeon, W.J. and Kwon, J.H. Antigenic and immunogenic investigation of the virulence motif of the Newcastle disease virus fusion protein. J Vet Sci. 11(3), 205-211(2010).

50. Naveen, K.A., Singh ,S.D., Kataria, J.M., Barathidasan, R. and Dhama, K. Molecular Characterization and Phylogenetic Analysis of Selected Pigeon Paramyxovirus Type-1 (PPMV-1) Indian Isolates. $J$. of Biological Sci., 14 (2),134-141 (2014).

51. Rajendren, V., Shoba, K., Ravikumar, G., Vairamuthu, S. and Murthy, T. Sequence Analysis of HN Protein Gene of Mesogenic Newcastle Disease Virus from Recent Outbreaks in Namakkal. Internat. J. Livestock Res., 8 (5), 302-312 (2018). doi: 10.5455/ijlr.20170808111637.

(Received 29/08/2018; accepted 25/09/2018) 


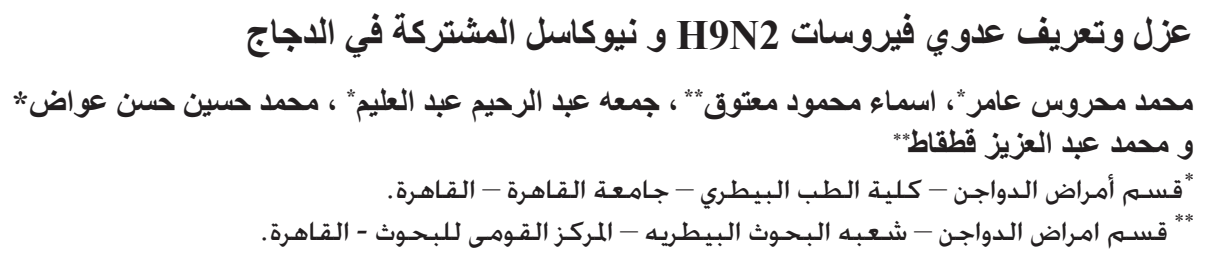

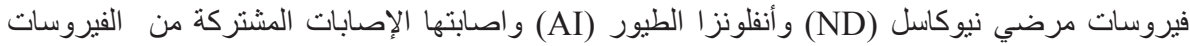

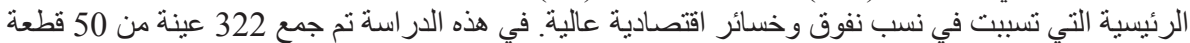

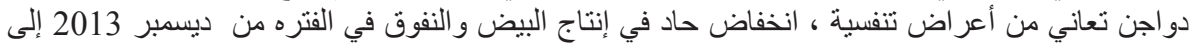

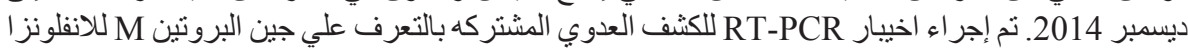

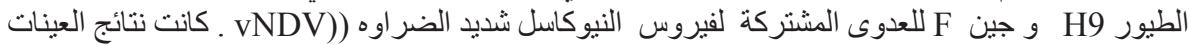

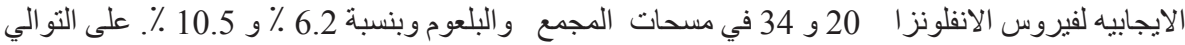

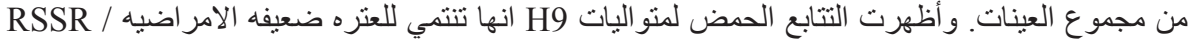

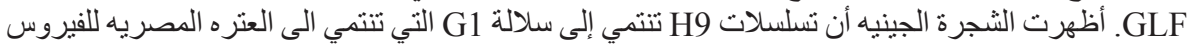

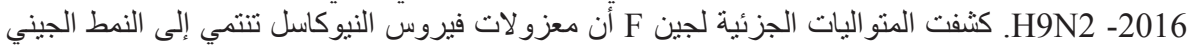

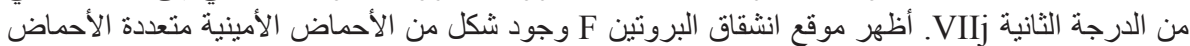

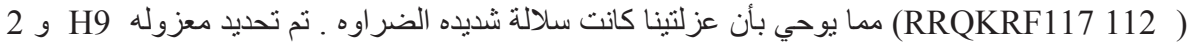

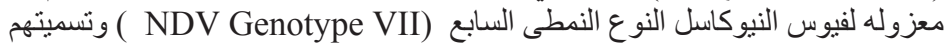
AI / CHICKEN / EGYPT / 48Ob / NRC-CU / 2014 (H9) ، NDV / CHICKEN / EGYPT

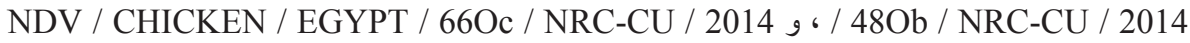
، وتم تقديم رفع تسلسلات النوكليوتيدات إلى بنك الجينات (Gen Bank) و واعطى أرقام

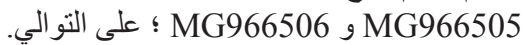

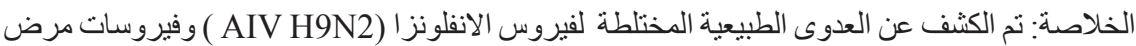
النيوكاسل ( NDV) من النوع النمطى السابع j في الطيور الداجنة التي تعاني من أعر اض تنفسية ونفوق في مصر.

الكلمات الدالة: فيروس الانفلونز ا H9N2 ، فيروس النيوكاسل النوع النمطي السابعـ تفاعل البلمره المتيلسل ،

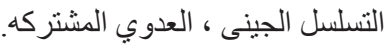

